\section{Cyclanilide Induces Lateral Branching in Sweet Cherry Trees}

\author{
Don C. Elfving ${ }^{1}$ and Dwayne B. Visser ${ }^{2}$ \\ Washington State University, Tree Fruit Research and Extension Center, \\ Wenatchee, WA 98801
}

Additional index words. plant growth regulator, bioregulator, Promalin, benzyladenine, gibberellic acid, auxin, cytokinin, feathering, feather production, vegetative growth, shoot growth, sylleptic shoots, Prunus avium

\begin{abstract}
A new bioregulator, cyclanilide (CYC, Bayer Environmental Science, Research Triangle Park, NC 27709), was compared with a proprietary formulation of 6-benzyladenine and gibberellins $A_{4}$ and $A_{7}$ [Promalin (PR), Valent BioSciences, Walnut Creek, Calif.] for branching effects on sweet cherry trees. CYC stimulated the formation of lateral shoots on current-season's shoot growth under both orchard and nursery conditions. In the nursery CYC was as effective or better for feathering compared to PR in all cherry cultivars tested. There were no synergistic effects of CYC/PR tank mixes on feather development. Crotch angles of induced feathers were not different from the angles of feathers that formed spontaneously. The growth of CYC-induced feathers was sufficient to produce acceptable quality feathered trees. Trunk caliper of nursery trees was either not affected or reduced to a very minimal degree. CYC is effective for lateral branch induction in sweet cherry, especially in the nursery. Chemical names used: 1-(2,4-dichlorophenylaminocarbonyl)cyclopropane carboxylic acid (cyclanilide); N-(phenylmethyl)-1H-purine-6-amine + gibberellins $A_{4}$ and $A_{7}$ (Promalin); polyoxyethylenepolypropoxypropanol, dihydroxypropane, 2-butoxyethanol (Regulaid).
\end{abstract}

The rapid development of lateral branching in apple trees favors early and increased yields (Ferree and Rhodus, 1987; Preston,1968; Quinlan,1978, 1981; Quinlan and Preston,1978; van Oosten, 1978, 1981; Wertheim 1978). For this reason apple trees with well-developed sylleptic shoots (feathers) from the nursery are preferred for high-density plantings. Much research has been conducted on stimulation of feathering in apple nursery trees (Elfving and Visser, 2005). In contrast, little research has been carried out on the induction of sylleptic shoot (feather) formation in sweet cherry trees. Many bioregulator products that stimulate lateral shoot development in apple or pear are ineffective when applied to sweet cherry (Cody et al., 1985b; Larsen, 1979; Plich and Basak, 1978; Quinlan and Preston, 1973). Application of the cytokinin 6-benzyladenine (BA) with or without gibberellic acid isomers $\mathrm{GA}_{4}$ and $\mathrm{GA}_{7}\left(\mathrm{GA}_{4+7}\right)$ improves feather formation in sweet cherry trees in the nursery (Cody et al., 1985a; Hrotkó et al., 1999; Neri et al., 2003; Wustenberghs and Keulemans, 1999), although cultivars display large differences in their response to such treatments (Wustenberghs and Keulemans, 1999).

Sweet cherry trees exhibit strong apical dominance, naturally producing a vigorous, upright growth habit with limited lateral branching in young trees (Miller, 1983;

Received for publication 8 Sept. 2005. Accepted for publication 16 Nov. 2005. We wish to express appreciation to Bayer Environmental Science, the Washington Tree Fruit Research Commission and the Washington Dept. of Agriculture Nursery Division for funds partially supporting these studies.

${ }^{1}$ Horticulturistand professor. To whom reprint requests should be addressed; e-mail delfving@wsu.edu.

${ }^{2}$ Agricultural research technologist III.
Veinbrants and Miller, 1981). Heavy pruning is often employed to induce lateral branch development, but this practice stimulates vigor and delays economic returns. The strength of apical dominance in apple has been related to the amount of auxin in shoot tips and its movement below the tip area (Abbas, 1978; Baldini et al., 1973); it is likely that a similar phenomenon is active in sweet cherry as well. Recently, the bioregulator cyclanilide (CYC), which appears to interfere with auxin transport and action (Pederson et al., 1997), was shown to induce feather development in nursery- and orchard-grown apple trees (Elfving and Visser, 2005). The research reported here was undertaken to evaluate the potential of $\mathrm{CYC}$ for inducing feather development in and to compare its effects on branch development with those of a proprietary mixture of 6-benzyladenine and gibberellic acid isomers $\mathrm{GA}_{4}$ and $\mathrm{GA}_{7}$ [Promalin (PR)] .

\section{Materials and Methods}

Five experiments were conducted between 2002 and 2003. All trials used randomized complete-block designs with at least 4 replications. Proprietary formulations of CYC (Bayer Environmental Science, Research Triangle Park, N.C.) and BA plus $\mathrm{GA}_{4+7}$ (PR, Valent BioSciences, Walnut Creek, Calif.) were used. All bioregulator treatments were supplemented with $0.1 \%$ v/v Regulaid (Kalo, Inc., Overland Park, Kan.). Orchard plots were sprayed to runoff with a Nifty motorized hydraulic sprayer and handgun; the nursery trials were carried out using a manually operated Solo backpack sprayer fitted with two spray heads that applied a dilute spray to the upper half of each sweet cherry trees in the orchard and nursery nursery tree. The orchard trees had no flowers or fruit the year of treatment. All bioregulator concentrations are expressed in terms of the active ingredient(s). The experiments are described below.

Experiment 1, 2002, Monitor, Wash. Applications of CYC and/or PR were made to single-tree plots in six randomized blocks of 'Bing'/Mazzard sweet cherry trees planted in a commercial orchard at a spacing of $6.1 \times$ $6.1 \mathrm{~m}$ in 2000. In Spring 2002 the trees were headed to encourage strong multiple leader development and were in vigorous shoot growth at the time of treatment. CYC at 50,100, or $200 \mathrm{mg} \cdot \mathrm{L}^{-1}$ was applied on 20 May (terminal shoots $27.0 \pm 0.4 \mathrm{~cm}$ ). On the same date, one additional tree in each block was treated with PR (500 $\left.\mathrm{mg} \cdot \mathrm{L}^{-1}\right)$ either alone or tank-mixed with CYC at 50 or $100 \mathrm{mg} \cdot \mathrm{L}^{-1}$. Control trees were unsprayed. After shoot growth was completed, three vigorous, upright shoots that grew in 2002 were selected on each test tree and the length of each shoot measured from its base to its tip. The length and crotch angle of each sylleptic shoot (feather) induced on each of these current-season's shoots were measured. The distance from the base of each 2002 shoot to the first induced feather was also measured.

Experiment 2, 2003, Bray's Landing, Wash. Applications of CYC and/or PR were made to single-tree plots in four randomized blocks of 'Rainier'/Mazzard sweet cherry trees planted in a commercial orchard at a spacing of $2.7 \times$ $4.9 \mathrm{~m}$ in 2002. The vigorous, upright shoots that developed in 2002 were each headed in early Spring 2003 before growth began to produce the steep-leader multiple-leader training system. The following treatments were applied either once to single-tree plots on 21 May [newly developing terminal shoots 26.8 $\pm 0.7 \mathrm{~cm}$ ) or twice (21 May and again 1 July (terminal shoots $101.1 \pm 1.7 \mathrm{~cm}$ )]: CYC 50 or $100 \mathrm{mg} \cdot \mathrm{L}^{-1}$, PR $250 \mathrm{mg} \cdot \mathrm{L}^{-1}, \mathrm{CYC} 50$ or 100 $\mathrm{mg} \cdot \mathrm{L}^{-1}+\mathrm{PR} 250 \mathrm{mg} \cdot \mathrm{L}^{-1}$ as a tank-mix (total of 11 treatments including control). Control trees were unsprayed. After shoot growth was completed, the newly developed terminal shoot from each of three headed 2002 shoots was selected and its length determined. The length and crotch angle of all feathers that were induced on each of the 2003 terminal shoots were measured. The distance from the base of each 2003 shoot to the first induced feather was also measured.

Spontaneous formation of feathers in low numbers on sweet cherry trees occurs frequently in the nursery. In the nursery trials, the occasional feathers formed well below the approximate height of the central leader at treatment were already growing at the time of treatment and were ignored.

Experiment 3, 2002, Quincy, Wash. CYC $\left(50\right.$ or $\left.100 \mathrm{mg} \cdot \mathrm{L}^{-1}\right)$, PR $\left(250 \mathrm{mg} \cdot \mathrm{L}^{-1}\right)$, or tankmixes of PR with each of the CYC concentrations were applied to 10-tree plots of nursery 'Bing' and 'Lapins'/Mazzard sweet cherry trees in four randomized blocks each on 5 July. 'Bing' trees averaged about $70 \mathrm{~cm}$ from bud union to shoot tip at the time of treatment while 'Lapins' trees averaged about $20 \mathrm{~cm}$ 
Table 1. Effects of cyclanilide (CYC) and/or Promalin (PR) applications on lateral branch (feather) formation in third-leaf 'Bing'/Mazzard sweet cherry trees in the orchard (Expt. 1, 2002) (Monitor, Wash.).

\begin{tabular}{|c|c|c|c|c|c|c|}
\hline \multirow[b]{2}{*}{$\begin{array}{l}\text { Treatment } \\
\left(\mathrm{mg} \cdot \mathrm{L}^{-1}\right)^{\mathrm{z}}\end{array}$} & \multirow[b]{2}{*}{$\begin{array}{l}\text { Shoot } \\
\text { length } \\
(\mathrm{cm})\end{array}$} & \multicolumn{3}{|c|}{ Feathers/shoot } & \multirow[b]{2}{*}{$\begin{array}{l}\text { Mean } \\
\text { feather } \\
\text { length } \\
(\mathrm{cm})\end{array}$} & \multirow[b]{2}{*}{$\begin{array}{c}\text { Crotch } \\
\text { angle } \\
\left(^{\circ}\right)\end{array}$} \\
\hline & & No. & $\begin{array}{c}\text { No./cm } \\
\text { shoot } \\
\text { length } \\
(\times 100)^{y}\end{array}$ & $\begin{array}{l}\text { Base to } \\
\text { first } \\
\text { feather } \\
(\mathrm{cm})\end{array}$ & & \\
\hline Control & $207 \mathrm{a}^{\mathrm{x}}$ & $0.8 \mathrm{c}$ & $0.4 \mathrm{c}$ & $40 \mathrm{a}$ & $62 \mathrm{a}$ & $49 \mathrm{a}$ \\
\hline CYC 50 & $195 \mathrm{a}$ & $7.1 \mathrm{ab}$ & $3.6 \mathrm{a}$ & $30 \mathrm{~b}$ & $42 \mathrm{bc}$ & $47 \mathrm{a}$ \\
\hline CYC 100 & $190 \mathrm{a}$ & $5.8 \mathrm{ab}$ & $2.9 \mathrm{ab}$ & $30 \mathrm{~b}$ & $47 \mathrm{~b}$ & $54 \mathrm{a}$ \\
\hline CYC 200 & $195 \mathrm{a}$ & $5.7 \mathrm{ab}$ & $2.9 \mathrm{ab}$ & $28 \mathrm{c}$ & $47 \mathrm{~b}$ & $50 \mathrm{a}$ \\
\hline PR 500 & $206 \mathrm{a}$ & $2.2 \mathrm{c}$ & $1.1 \mathrm{c}$ & $40 \mathrm{a}$ & $50 \mathrm{~b}$ & $47 \mathrm{a}$ \\
\hline CYC $50+$ PR 500 & $202 \mathrm{a}$ & $5.0 \mathrm{~b}$ & $2.4 \mathrm{~b}$ & $36 \mathrm{ab}$ & $44 \mathrm{bc}$ & $50 \mathrm{a}$ \\
\hline CYC $100+$ PR 500 & $194 \mathrm{a}$ & $7.8 \mathrm{a}$ & $4.0 \mathrm{a}$ & $33 \mathrm{bc}$ & $33 \mathrm{c}$ & $49 \mathrm{a}$ \\
\hline
\end{tabular}

${ }^{2}$ Dilute applications with hydraulic sprayer 20 May 2002 (terminal shoots $27.0 \pm 0.4 \mathrm{~cm}$ ).

${ }^{y}$ Actual shoot no. per $\mathrm{cm}$ ratio values multiplied by 100 before analysis to facilitate presentation.

${ }^{\mathrm{x}}$ Mean separation in columns by Waller-Duncan Bayesian $\mathrm{k}$ ratio test following significant $\mathrm{F}$ test $(P \leq 0.05)$.

taller. Control trees were unsprayed. The trees were removed from the nursery in November 2002, bundled by replication and stored for further evaluation. For each cultivar, three representative trees from each replication were selected for detailed measurements. The following measurements were taken on each tree: 1) length of central leader from bud union to tip, 2) total number of feathers (any lateral shoot $>10 \mathrm{~cm}$ in length) originating near or above the approximate height of the central leader at the time of treatment, 3) length of each feather, 4) crotch angle of each feather, and 5) distance from bud union to the first induced feather.

Experiment 4, 2003, Quincy, Wash. CYC $\left(100 \mathrm{mg} \cdot \mathrm{L}^{-1}\right)$ with or without PR $\left(500 \mathrm{mg} \cdot \mathrm{L}^{-1}\right)$ as a tank-mix was applied to 15 -tree plots of nursery trees of 'Bing' and 'Skeena'/Mazzard sweet cherry trees in four randomized blocks on 16 June, when the newly developing centralleader shoot tips were about $60 \mathrm{~cm}$ above the bud unions. Control trees were unsprayed and another group of 15 trees in each block was treated with PR $\left(500 \mathrm{mg} \cdot \mathrm{L}^{-1}\right)$ on the same date. The trees were removed from the nursery in November 2003, bundled by replication, and stored for further evaluation. Ten representative trees were selected from each replication for growth measurements, which included 1) caliper $10 \mathrm{~cm}$ above the bud union, 2) length of the central-leader shoot from the bud union to the tip, 3) the number of feathers (any lateral shoot $>10 \mathrm{~cm}$ in length) originating near or above the approximate height of the central leader at the time of treatment, and 4) the distance from the bud union to the first induced feather. On three of the 10 trees additional measurements were made of 1) the length of each feather and 2) the crotch angle of each feather. All 'Skeena' trees were topped in the field before digging and storing.

Experiment 5, 2003, Quincy, Wash. CYC $\left(50\right.$ or $\left.100 \mathrm{mg} \cdot \mathrm{L}^{-1}\right)$ with or without PR (500 $\left.\mathrm{mg} \cdot \mathrm{L}^{-1}\right)$ as a tank-mix was applied to 15 -tree plots of nursery trees of 'Lapins'/Mazzard sweet cherry trees in four randomized blocks on 16 June, when the newly developing centralleader shoot tips were about $90 \mathrm{~cm}$ above the bud unions. Control trees were unsprayed and another group of 15 trees in each block was treated with PR $\left(500 \mathrm{mg} \cdot \mathrm{L}^{-1}\right)$ on the same date. The trees were removed from the nursery in November 2003, bundled by replication, and

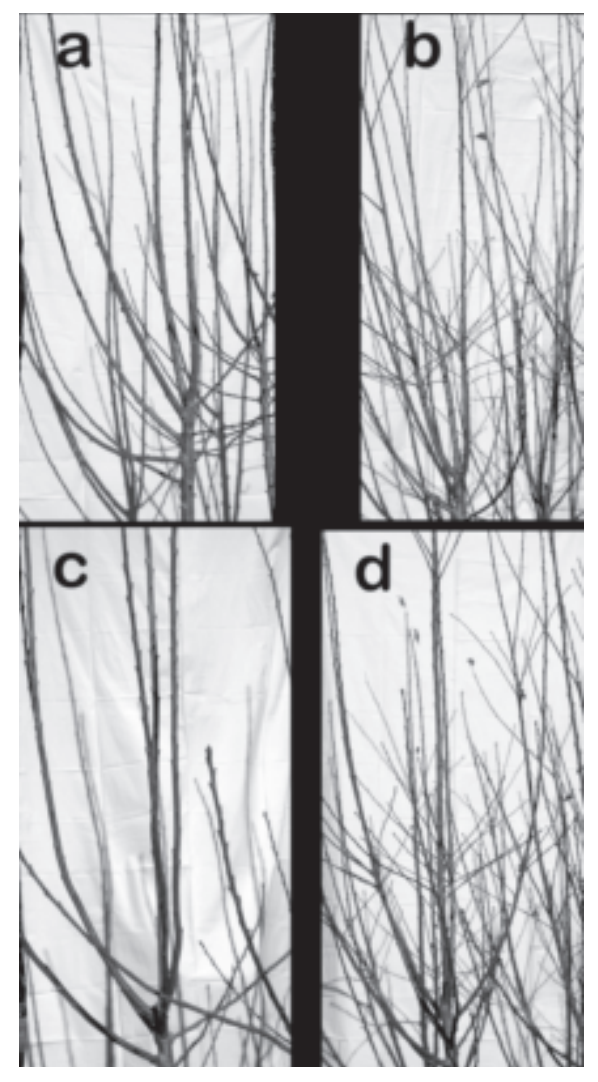

Fig. 1. Experiment 1 ('Bing'/Mazzard, orchard, 2002). (a) Control shoot growth from headed leaders in 2002; (b) CYC $100 \mathrm{mg} \cdot \mathrm{L}^{-1}$ applied 20 May; (c) PR $500 \mathrm{mg} \cdot \mathrm{L}^{-1}$ applied $20 \mathrm{May}$; (d) CYC $100 \mathrm{mg} \cdot \mathrm{L}^{-1}+\mathrm{PR} 500 \mathrm{mg} \cdot \mathrm{L}^{-1}$ tank mix applied 20 May. Note the cluster of feathers located near the base of each 2002 shoot in b and d, illustrating the temporary release of newly formed buds from apical dominance due to CYC treatment. treatment(Table 1). CYC induced about 6-fold

Table 2. Effects of cyclanilide (CYC) and/or Promalin (PR) applications on lateral branch (feather) formation in second leaf 'Rainier'/Mazzard sweet cherry trees in the orchard (Expt. 2, 2003) (Bray's Landing, Wash.).

\begin{tabular}{|c|c|c|c|c|c|c|}
\hline \multirow[b]{2}{*}{$\begin{array}{l}\text { Treatment } \\
\left(\mathrm{mg} \cdot \mathrm{L}^{-1}\right)^{\mathrm{z}}\end{array}$} & \multirow[b]{2}{*}{$\begin{array}{l}\text { Shoot } \\
\text { length } \\
(\mathrm{cm})\end{array}$} & \multicolumn{3}{|c|}{ Feathers/shoot } & \multirow[b]{2}{*}{$\begin{array}{l}\text { Mean } \\
\text { feather } \\
\text { length } \\
(\mathrm{cm})\end{array}$} & \multirow[b]{2}{*}{$\begin{array}{c}\text { Crotch } \\
\text { angle } \\
\left(^{\circ}\right)\end{array}$} \\
\hline & & No. & $\begin{array}{c}\text { No./cm } \\
\text { shoot } \\
\text { length } \\
(\times 100)^{y}\end{array}$ & $\begin{array}{l}\text { Base to } \\
\text { first } \\
\text { feather } \\
(\mathrm{cm})\end{array}$ & & \\
\hline Control & $207 \mathrm{ab}^{\mathrm{x}}$ & $1.2 \mathrm{e}$ & $0.5 \mathrm{f}$ & $40 \mathrm{abc}$ & $99 a$ & $48 \mathrm{abc}$ \\
\hline CYC $50,1 \times$ & $207 \mathrm{ab}$ & $6.8 \mathrm{abcd}$ & 3.2 abcde & $32 \mathrm{abc}$ & $62 \mathrm{bc}$ & $47 \mathrm{abc}$ \\
\hline CYC $50,2 \times$ & $174 \mathrm{ab}$ & $7.6 \mathrm{abc}$ & $4.5 \mathrm{ab}$ & $31 \mathrm{abc}$ & $54 \mathrm{bc}$ & $47 \mathrm{abc}$ \\
\hline CYC $100,1 \times$ & $197 \mathrm{ab}$ & $8.2 \mathrm{ab}$ & $4.1 \mathrm{abc}$ & $29 \mathrm{bc}$ & $47 \mathrm{bc}$ & $52 \mathrm{a}$ \\
\hline CYC $100,2 \times$ & $157 \mathrm{~b}$ & 3.8 cde & $2.1 \mathrm{cdef}$ & $27 \mathrm{c}$ & $44 \mathrm{c}$ & $40 \mathrm{c}$ \\
\hline PR $250,1 \times$ & $204 \mathrm{ab}$ & $3.2 \mathrm{de}$ & $1.6 \mathrm{ef}$ & $45 \mathrm{a}$ & $70 \mathrm{~b}$ & $44 \mathrm{abc}$ \\
\hline PR $250,2 \times$ & $213 \mathrm{a}$ & 4.2 cde & $1.9 \mathrm{def}$ & $44 \mathrm{ab}$ & $70 \mathrm{~b}$ & $42 \mathrm{bc}$ \\
\hline CYC $50+$ PR $250,1 \times$ & $173 \mathrm{ab}$ & 4.9 bcde & 2.7 bcde & $30 \mathrm{abc}$ & $39 \mathrm{c}$ & $51 \mathrm{ab}$ \\
\hline CYC $50+$ PR $250,2 \times$ & $201 \mathrm{ab}$ & $7.7 \mathrm{abc}$ & $3.8 \mathrm{abcd}$ & $41 \mathrm{abc}$ & $55 \mathrm{bc}$ & $45 \mathrm{abc}$ \\
\hline CYC $100+$ PR $250,1 \times$ & $202 \mathrm{ab}$ & $9.1 \mathrm{a}$ & $4.6 \mathrm{ab}$ & $29 \mathrm{bc}$ & $46 \mathrm{bc}$ & $47 \mathrm{abc}$ \\
\hline CYC $100+$ PR $250,2 \times$ & $184 \mathrm{ab}$ & $9.2 \mathrm{a}$ & $5.0 \mathrm{a}$ & $30 \mathrm{abc}$ & $53 \mathrm{bc}$ & $47 \mathrm{abc}$ \\
\hline \multicolumn{7}{|l|}{ Orthogonal contrasts } \\
\hline Control vs. all treatments & NS & $*$ & $*$ & $*$ & * & NS \\
\hline All CYC vs. all PR & $*$ & $*$ & $*$ & $*$ & $*$ & $*$ \\
\hline $\begin{array}{l}\text { Single application vs. } \\
\text { double application }\end{array}$ & NS & NS & NS & $*$ & NS & $*$ \\
\hline \multicolumn{7}{|l|}{ Single applicatio CYC 50} \\
\hline vs. $100 \mathrm{mg} \cdot \mathrm{L}^{-1}$ & NS & $*$ & $*$ & NS & NS & NS \\
\hline
\end{tabular}

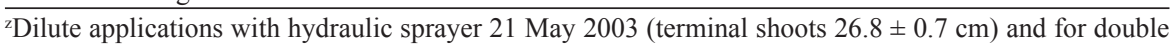
applications 1 July 2003 (terminal shoots $101.0 \pm 1.7 \mathrm{~cm}$ ).

${ }^{y}$ Actual shoot no. per $\mathrm{cm}$ ratio values multiplied by 100 before analysis to facilitate presentation.

${ }^{\mathrm{x}}$ Mean separation in columns by Waller-Duncan Bayesian $\mathrm{k}$ ratio test following significant $\mathrm{F}$ test $(P \leq 0.05)$.

NS, ${ }^{*}$ Nonsignificant or significant at $P \leq 0.05$. 
more new lateral (sylleptic) shoots (feathers) and comparably increased their density on the current-season's developing shoots than originated naturally, regardless of the concentration used, although some phytotoxicity to foliage was observed at the highest concentration. PR alone did not produce greater development of feathers than on untreated trees and did not improve the feathering response to CYC when tank-mixed (Fig. 1). The distance from the shoot base to the first feather was shorter for $\mathrm{CYC}$ treatments and the $\mathrm{CYC} 100 \mathrm{mg} \cdot \mathrm{L}^{-1}$ + PR $500 \mathrm{mg} \cdot \mathrm{L}^{-1}$ treatment. All bioregulator treatments resulted in shorter feathers than in untreated trees, where very low incidence of sylleptic shoots coincided with the longest mean length. However, induced feathers were well-developed by the end of the growing

Table 3. Effects of cyclanilide (CYC) and/or Promalin (PR) applications on feather formation in 'Bing'/ Mazzard sweet cherry trees in the nursery (Expt. 3, 2002) (Quincy, Wash.).

\begin{tabular}{|c|c|c|c|c|c|c|}
\hline \multirow{3}{*}{$\begin{array}{l}\text { Growth } \\
\text { regulator } \\
\left(\mathrm{mg} \cdot \mathrm{L}^{-1}\right)^{\mathrm{z}}\end{array}$} & \multirow{3}{*}{$\begin{array}{l}\text { Leader } \\
\text { length } \\
(\mathrm{cm})\end{array}$} & \multicolumn{5}{|c|}{ Induced feathers } \\
\hline & & \multirow{2}{*}{$\begin{array}{l}\text { No./ } \\
\text { shoot }\end{array}$} & \multicolumn{2}{|c|}{$\begin{array}{l}\text { Union to first } \\
\text { induced feather } \\
(\mathrm{cm})\end{array}$} & \multirow{2}{*}{$\begin{array}{l}\text { Mean } \\
\text { length } \\
(\mathrm{cm})\end{array}$} & \multirow{2}{*}{$\begin{array}{l}\text { Crotch } \\
\text { angle } \\
\left(^{\circ}\right)\end{array}$} \\
\hline & & & $-\mathrm{PR}$ & $+\mathrm{PR}$ & & \\
\hline \multicolumn{7}{|l|}{$\overline{\mathrm{CYC}}$} \\
\hline 0 & 175 & 1.2 & 113 & 85 & 43 & 37 \\
\hline 50 & 178 & 2.6 & 83 & 84 & 48 & 37 \\
\hline 100 & 167 & 4.6 & 81 & 84 & 41 & 38 \\
\hline \multicolumn{7}{|l|}{ Significance } \\
\hline CYC linear & NS & $* * * *$ & $* *$ & NS & NS & NS \\
\hline CYC quadratic & NS & NS & $*$ & NS & NS & NS \\
\hline \multicolumn{7}{|l|}{ PR } \\
\hline 0 & $174 a^{y}$ & $2.1 \mathrm{~b}$ & $88 \mathrm{a}$ & --- & $47 \mathrm{a}$ & $38 \mathrm{a}$ \\
\hline 250 & $173 \mathrm{a}$ & $4.2 \mathrm{a}$ & --- & $85 \mathrm{a}$ & $42 \mathrm{a}$ & $37 \mathrm{a}$ \\
\hline \multicolumn{7}{|l|}{ Interaction } \\
\hline $\mathrm{CYC} \times \mathrm{PR}$ & NS & NS & $*$ & & NS & NS \\
\hline
\end{tabular}

${ }^{2}$ Dilute applications with hydraulic sprayer 5 July 2002 (central leader about $70 \mathrm{~cm}$ in length). ${ }^{y}$ Mean separation in columns by $\mathrm{F}$ test $(P \leq 0.05)$.

$\mathrm{NS},{ }^{*, * *, * * *, * * * *}$ Nonsignificant or significant analysis of regression at $P \leq 0.05,0.01,0.001$, or 0.0001 .

Table 4. Effects of cyclanilide (CYC) and/or Promalin (PR) applications on feather formation in 'Lapins'/ Mazzard sweet cherry trees in the nursery (Expt. 3, 2002) (Quincy, Wash.).

\begin{tabular}{|c|c|c|c|c|c|c|}
\hline \multirow{3}{*}{$\begin{array}{l}\text { Growth } \\
\text { regulator } \\
\left(\mathrm{mg} \cdot \mathrm{L}^{-1}\right)^{\mathrm{z}}\end{array}$} & \multirow{3}{*}{$\begin{array}{l}\text { Leader } \\
\text { length } \\
(\mathrm{cm})\end{array}$} & \multicolumn{5}{|c|}{ Induced feathers } \\
\hline & & \multirow{2}{*}{$\begin{array}{l}\text { No./ } \\
\text { shoot }\end{array}$} & \multicolumn{2}{|c|}{$\begin{array}{l}\text { Union to first } \\
\text { induced feather } \\
(\mathrm{cm})\end{array}$} & \multirow{2}{*}{$\begin{array}{l}\text { Mean } \\
\text { length } \\
(\mathrm{cm})\end{array}$} & \multirow{2}{*}{$\begin{array}{l}\text { Crotch } \\
\text { angle } \\
\left({ }^{\circ}\right)\end{array}$} \\
\hline & & & $-\mathrm{PR}$ & $\overline{+P R}$ & & \\
\hline \multicolumn{7}{|l|}{$\mathrm{CYC}$} \\
\hline 0 & 209 & 2.0 & 131 & 126 & 36 & 39 \\
\hline 50 & 193 & 4.1 & 108 & 117 & 34 & 40 \\
\hline 100 & 194 & 5.7 & 109 & 112 & 32 & 38 \\
\hline \multicolumn{7}{|l|}{ Significance } \\
\hline CYC linear & * & $* * * *$ & $* * * *$ & NS & NS & NS \\
\hline CYC quadratic & NS & NS & $* *$ & NS & NS & NS \\
\hline \multicolumn{7}{|l|}{ 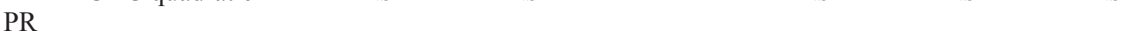 } \\
\hline 0 & $196 \mathrm{a}^{\mathrm{y}}$ & $3.9 \mathrm{a}$ & $116 \mathrm{a}$ & --- & $33 \mathrm{a}$ & $38 \mathrm{a}$ \\
\hline 250 & $202 \mathrm{a}$ & $4.0 \mathrm{a}$ & --- & $118 \mathrm{a}$ & $35 \mathrm{a}$ & $39 a$ \\
\hline \multicolumn{7}{|l|}{ Interaction } \\
\hline $\mathrm{CYC} \times \mathrm{PR}$ & NS & NS & $*$ & & NS & NS \\
\hline
\end{tabular}

${ }^{2}$ Dilute applications with hydraulic sprayer 5 July 2002 (central leader about $90 \mathrm{~cm}$ in length).

${ }^{y}$ Mean separation in columns by $\mathrm{F}$ test $(P \leq 0.05)$.

$\mathrm{NS}, *, * *, * * *, * * * * *$ Nonsignificant or significant analysis of regression at $=P \leq 0.05,0.01,0.001$, or 0.0001 .

Table 5. Effects of cyclanilide (CYC) and/or Promalin (PR) applications on feather formation in 'Bing'/ Mazzard sweet cherry trees in the nursery (Expt. 4, 2003) (Quincy, Wash.).

\begin{tabular}{|c|c|c|c|c|c|c|}
\hline \multirow[b]{2}{*}{$\begin{array}{l}\text { Growth } \\
\text { regulator } \\
\left(\mathrm{mg} \cdot \mathrm{L}^{-1}\right)^{z}\end{array}$} & \multirow[b]{2}{*}{$\begin{array}{l}\text { Trunk } \\
\text { caliper } \\
(\mathrm{mm})\end{array}$} & \multirow[b]{2}{*}{$\begin{array}{l}\text { Leader } \\
\text { length } \\
(\mathrm{cm})\end{array}$} & \multicolumn{4}{|c|}{ Induced feathers } \\
\hline & & & $\begin{array}{l}\text { No./ } \\
\text { shoot }\end{array}$ & $\begin{array}{l}\text { Union to } \\
\text { first } \\
\text { induced } \\
\text { feather } \\
(\mathrm{cm})\end{array}$ & $\begin{array}{l}\text { Mean } \\
\text { length } \\
(\mathrm{cm})\end{array}$ & $\begin{array}{c}\text { Crotch } \\
\text { angle } \\
\left({ }^{\circ}\right)\end{array}$ \\
\hline \multicolumn{7}{|l|}{$\overline{\mathrm{CYC}}$} \\
\hline 0 & $20 \mathrm{a}^{\mathrm{y}}$ & $242 \mathrm{a}$ & $2.7 \mathrm{~b}$ & $94 \mathrm{a}$ & $57 \mathrm{a}$ & $41 \mathrm{a}$ \\
\hline 100 & $19 \mathrm{~b}$ & $233 \mathrm{~b}$ & $8.1 \mathrm{a}$ & $81 \mathrm{~b}$ & $45 \mathrm{~b}$ & $39 \mathrm{~b}$ \\
\hline \multicolumn{7}{|l|}{ PR } \\
\hline 0 & $19 \mathrm{a}$ & $240 \mathrm{a}$ & $3.7 \mathrm{~b}$ & $89 \mathrm{a}$ & $56 \mathrm{a}$ & $40 \mathrm{a}$ \\
\hline 500 & $19 \mathrm{a}$ & $235 \mathrm{~b}$ & $7.1 \mathrm{a}$ & $86 \mathrm{a}$ & $46 \mathrm{~b}$ & $40 \mathrm{a}$ \\
\hline
\end{tabular}

${ }^{2}$ Dilute applications with hydraulic sprayer 16 June 2003 (central leader about $70 \mathrm{~cm}$ in length).

y Mean separation in columns within treatments by $\mathrm{F}$ test $(P \leq 0.05)$. No significant $\mathrm{CYC} \times \mathrm{PR}$ interactive effects. season. Crotch angles were unaffected by any treatment.

Experiment 2. There were a few differences in the lengths of the new terminal shoots developed in 2003 but no treatment produced different lengths compared to shoots on control trees (Table 2). The number of induced feathers and their density on the 2003 shoots were both increased substantially by CYC treatment, except for CYC $100 \mathrm{mg} \cdot \mathrm{L}^{-1}$ applied twice. PR treatment did not improve feathering beyond controls and did not improve the branching response to CYC when tank-mixed. No advantage in feather number or growth and development resulted from double applications of CYC. Mean feather length was shorter for all treatments, including those that did not improve branching. However, induced feathers were well-developed by the end of the growing season. While there were some statistically significant differences in crotch angle, no treatment produced any effects compared to controls and differences were minor.

Experiment 3. Final central leader length in nursery 'Bing' trees was not affected by any bioregulator treatment in 2002 (Table 3). Feathering was improved in direct proportion to CYC concentration; PR also increased feather development but its effect was not interactive with CYC. In the absence of PR, CYC produced feathers at a lower height on the shoots than occurred naturally, but when PR was included, induced feathers originated at a similar height regardless of CYC concentration. There were no effects of bioregulators on feather crotch angle. Mean feather length was not affected by either product. Leader length was slightly reduced by CYC in 'Lapins' but unaffected by PR (Table 4). As in 'Bing', feather production in 'Lapins' was increased by CYC in proportion to concentration. The distance to first induced feather was shorter in the absence of PR, but there were no effects of CYC or PR on mean feather length or crotch angle. 'Lapins' is reported to be a difficult-to-branch cultivar (Wustenberghs and Keulemans, 1999). PR did not improve feathering or affect feather growth in 'Lapins' in 2002.

Experiment 4. In 2003, feather development in both 'Bing' and 'Skeena' was increased by both CYC and PR (Tables 5 and 6, Fig. 2). CYC reduced the height to first feather and mean feather length in both cultivars and reduced total leader length slightly in 'Bing', but had only minor or no effects on trunk caliper or branch crotch angle in either cultivar.

Experiment 5. CYC increased feather development on 'Lapins' in 2003 in the presence or absence of PR (Table 7, Fig. 3). CYC produced minor effects on trunk caliper, leader length, height to feather and crotch angle; CYC had no effect on mean feather length despite the increase in number. The only effect of PR was to produce a small increase in feather development.

\section{Discussion}

Although sweet cherry trees may produce a small amount of sylleptic shoot (feather) development spontaneously, particularly in the 
Table 6. Effects of cyclanilide (CYC) and/or Promalin (PR) applications on feather formation in 'Skeena'/Mazzard sweet cherry trees in the nursery (Expt. 4, 2003) (Quincy, Wash.).

\begin{tabular}{|c|c|c|c|c|c|c|c|}
\hline \multirow[b]{2}{*}{$\begin{array}{l}\text { Growth } \\
\text { regulator } \\
\left(\mathrm{mg} \cdot \mathrm{L}^{-1}\right)^{\mathrm{z}}\end{array}$} & \multirow[b]{2}{*}{$\begin{array}{c}\text { Trunk } \\
\text { caliper } \\
(\mathrm{mm})\end{array}$} & \multirow[b]{2}{*}{$\begin{array}{l}\text { Leader } \\
\text { length } \\
(\mathrm{cm})\end{array}$} & \multicolumn{5}{|c|}{ Induced feathers } \\
\hline & & & $\begin{array}{c}\text { No./ } \\
\text { shoot }\end{array}$ & $\begin{array}{l}\text { Union to } \\
\text { first } \\
\text { induced } \\
\text { feather } \\
(\mathrm{cm})\end{array}$ & $\begin{array}{l}\text { Crotch } \\
\text { angle } \\
\left({ }^{\circ}\right)\end{array}$ & $\begin{array}{c}\text { Treatment } \\
\left(\mathrm{mg} \cdot \mathrm{L}^{-1}\right)\end{array}$ & $\begin{array}{c}\text { Mean } \\
\text { feather } \\
\text { length } \\
(\mathrm{cm})\end{array}$ \\
\hline \multicolumn{8}{|l|}{$\overline{\mathrm{CYC}}$} \\
\hline 0 & $24 \mathrm{a}^{\mathrm{y}}$ & $177 \mathrm{a}$ & $2.4 \mathrm{~b}$ & $78 \mathrm{a}$ & $36 \mathrm{a}$ & Control & $82 \mathrm{a}$ \\
\hline 100 & $22 \mathrm{a}$ & $178 \mathrm{a}$ & $7.6 \mathrm{a}$ & $72 b$ & 39 a & $\begin{array}{c}\text { PR } 500 \\
\text { CYC } 100\end{array}$ & $\begin{array}{l}60 b \\
43 c\end{array}$ \\
\hline PR & & & & & & CYC $100+$ PR 500 & $40 c^{x}$ \\
\hline 0 & $23 \mathrm{a}$ & $178 \mathrm{a}$ & $4.3 \mathrm{~b}$ & $72 \mathrm{a}$ & $38 \mathrm{a}$ & & \\
\hline 500 & $23 \mathrm{a}$ & $178 \mathrm{a}$ & $5.6 \mathrm{a}$ & $77 \mathrm{a}$ & $36 \mathrm{a}$ & & \\
\hline
\end{tabular}

${ }^{2}$ Dilute applications with hydraulic sprayer 16 June 2003 (central leader about $60 \mathrm{~cm}$ in length).

${ }^{\mathrm{y}}$ Mean separation in columns by Waller-Duncan Bayesian $\mathrm{k}$ ratio test following significant $\mathrm{F}$ test for interaction $(P \leq 0.05)$.

${ }^{x}$ Mean separation in columns within treatments by F test $(P \leq 0.05)$. CYC $\times \mathrm{PR}$ interactive effect significant only for mean feather length.

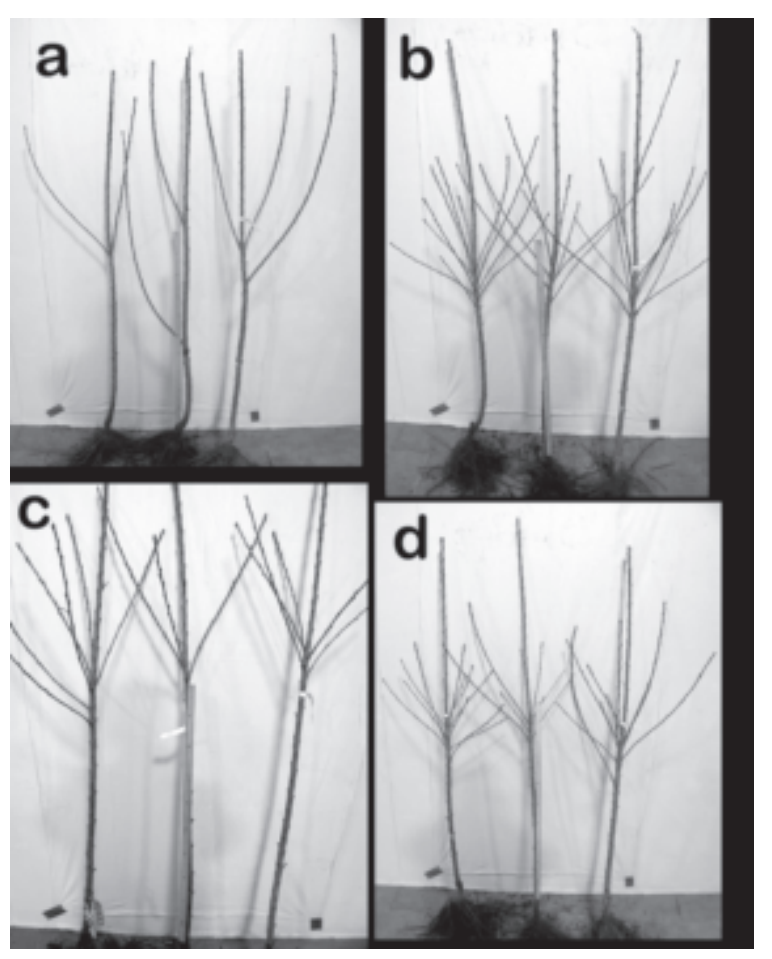

nursery, the numbers, distribution and growth of these shoots make them unsuitable for re-
Fig. 2. Experiment 4 ('Skeena'/Mazzard, nursery, 2003). Note meter stick in each picture. (a) Control trees. Note limited numbers and poor distribution of spontaneous feathers; (b) CYC 100 $\mathrm{mg} \cdot \mathrm{L}^{-1}$ applied 16 June; good lateral distribution and development; note cluster of shoots indicating limited action of a single CYC application in reducing apical dominance; (c) PR $500 \mathrm{mg} \cdot \mathrm{L}^{-1}$ applied 16 June; limited feathering; (d) tank-mix of CYC and PR applied 16 June; feathering similar to $\mathbf{b}$.

tention as part of a well-trained canopy and they are normally removed when nursery trees are planted. In the trials reported here, PR produced some feather development, but the feathering response to $\mathrm{CYC}$ was more uniform and consistent across the cultivars used. CYC improved the circumferential distribution of lateral shoots as well as the uniformity of the height at which feathering occurred. Applying CYC and/or PR twice to 'Rainier' trees in the orchard did not result in better feathering than a single application. Combining
CYC with PR produced no synergistic effect on feather formation in any trial. CYC appears particularly promising for the production of feathered sweet cherry trees in the nursery because of its strong and consistent stimulation of well-developed lateral shoots. Few other bioregulators have been reported to produce suitable feathering in sweet cherry. Likewise, chemical pinching agents that have been found to induce branching by damaging apple nursery-tree shoot tips have generally shown little effect on sweet cherries (Cody et al., 1985b; Larsen, 1979; Plich and Basak, 1978).

CYC displays an additional advantage for feathering of nursery sweet cherry trees because it does not produce horticulturally significant long-term reduction of or deformation of growth of the terminal meristem even though it temporarily interrupts apical dominance. The development of an equivalent central leader in height after treatment is a critical feature of any branch-induction product for use in the nursery, where a strong central axis carrying several well-developed lateral shoots is the desired tree structure. In these trials, the occasional small effect of CYC on central leader length would not be considered important. The data presented here suggest that CYC has considerable potential as a feathering agent for sweet cherry, especially under nursery conditions.

Table 7. Effects of cyclanilide (CYC) and/or Promalin (PR) applications on feather formation in 'Lapins'/Mazzard sweet cherry trees in the nursery (Expt. 5, 2003) (Quincy, Wash.).

\begin{tabular}{|c|c|c|c|c|c|c|c|}
\hline \multirow[b]{2}{*}{$\begin{array}{l}\text { Growth } \\
\text { regulator } \\
\left(\mathrm{mg} \cdot \mathrm{L}^{-1}\right)^{2}\end{array}$} & \multirow[b]{2}{*}{$\begin{array}{c}\text { Trunk } \\
\text { caliper } \\
(\mathrm{mm})\end{array}$} & \multirow[b]{2}{*}{$\begin{array}{l}\text { Leader } \\
\text { length } \\
(\mathrm{cm})\end{array}$} & \multicolumn{5}{|c|}{ Induced feathers } \\
\hline & & & $\begin{array}{l}\text { No. } \\
\text {-PR }\end{array}$ & $\begin{array}{l}\text { No. } \\
+ \text { PR }\end{array}$ & $\begin{array}{l}\text { Union to } \\
\text { first } \\
\text { feather } \\
\text { induced } \\
\text { (cm) }\end{array}$ & $\begin{array}{l}\text { Mean } \\
\text { length } \\
(\mathrm{cm})\end{array}$ & $\begin{array}{c}\text { Crotch } \\
\text { angle } \\
\left({ }^{\circ}\right)\end{array}$ \\
\hline \multicolumn{8}{|l|}{$\overline{\mathrm{CYC}}$} \\
\hline 0 & 22 & 273 & 0.2 & 4.3 & 119 & 53 & 41 \\
\hline 50 & 22 & 269 & 4.1 & 5.6 & 114 & 52 & 40 \\
\hline CYC linear & * & * & $* * * *$ & * & $* * *$ & NS & * \\
\hline CYC quadratic & NS & NS & $* *$ & NS & NS & NS & NS \\
\hline \multicolumn{8}{|l|}{ PR } \\
\hline 0 & $22 \mathrm{a}^{\mathrm{y}}$ & $266 \mathrm{a}$ & $3.1 \mathrm{~b}$ & --- & $111 \mathrm{a}$ & $51 \mathrm{a}$ & $39 \mathrm{a}$ \\
\hline 500 & $22 \mathrm{a}$ & $271 \mathrm{a}$ & --- & $5.8 \mathrm{a}$ & $115 \mathrm{a}$ & $52 \mathrm{a}$ & $40 \mathrm{a}$ \\
\hline \multicolumn{8}{|l|}{ Interaction } \\
\hline $\mathrm{CYC} \times \mathrm{PR}$ & NS & NS & * & & NS & NS & NS \\
\hline
\end{tabular}

${ }^{2}$ Dilute applications with hydraulic sprayer 16 June 2003 (central leader about $95 \mathrm{~cm}$ in length).

${ }^{y}$ Mean separation in columns by $\mathrm{F}$ test $(P \leq 0.05)$.

$\mathrm{NS}^{*, * * * * * * *, * * * * *}$ Nonsignificant or significant analysis of regression at $=P \leq 0.05,0.01,0.001$, or 0.0001 . 


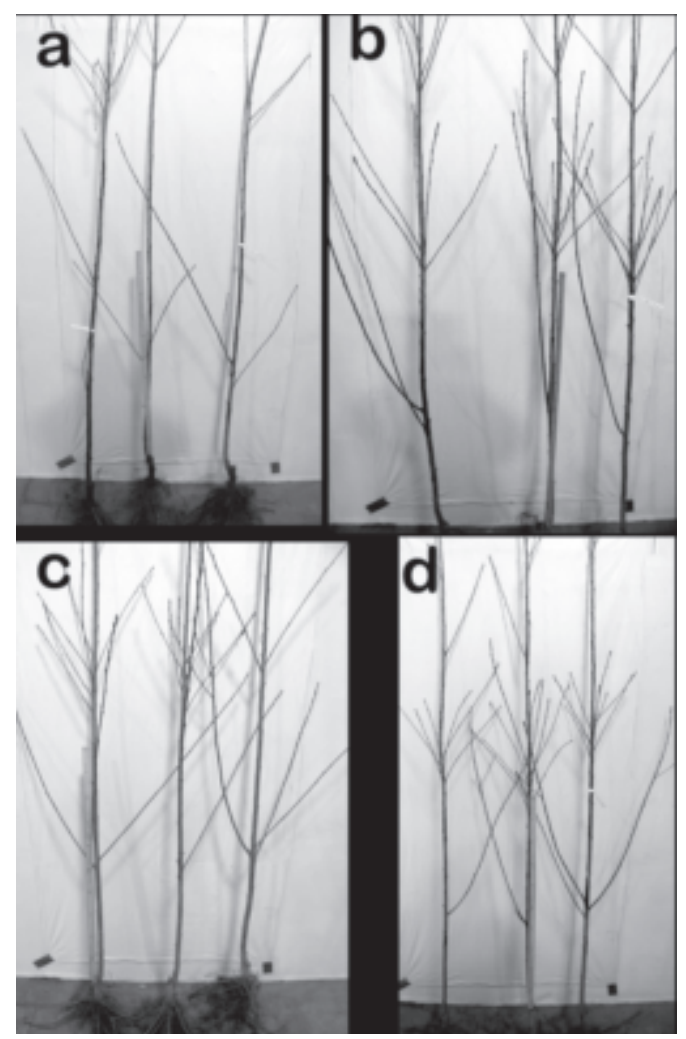

\section{Literature Cited}

Abbas, M.F. 1978. Association between branching in maiden apple trees and levels of endogenous auxins. Acta Hort 80:59-62.

Baldini, E., S. Sansavini, and A. Zocca. 1973. Induction of feathers by growth regulators on maiden trees of apple and pear. J. Hort. Sci. 48:327-337.

Cody, C.A., F.E. Larsen, and R. Fritts, Jr. 1985a. Stimulation of lateral branch development in tree fruit nursery stock with $\mathrm{GA}_{4+7}+$ BA. HortScience 20:758-759.

Cody, C.A., F.E. Larsen, and R. Fritts, Jr. 1985b. Induction of lateral branches in tree fruit nursery stock with propyl-3t-butylphenoxy acetate (M\&B 25, 105) and Promalin $\left(\mathrm{GA}_{4+7}+6\right.$-benzyladenine $)$. Scientia Hort. 26:111-118.

Elfving, D.C. 1990. Growth and productivity of 'Empire' apple trees following a single heading-back pruning treatment. HortScience 25:908-910.

Elfving, D.C. and D.B. Visser. 2005. Cyclanilide induces lateral branching in apple trees. HortScience 40:119-122.

Ferree, D.C. and W.T. Rhodus. 1987. Early performance and economic value of feathered apple trees on semi-standard rootstocks. J. Amer. Soc. Hort. Sci. 112:906-909.

Hrotkó, K., L. Magyar, and B. Öri. 1999. Improved feathering on one-year-old 'Germersdorfi FL 45 ' sweet cherry trees in the nursery. Gartenbauwiss. 64:75-78.

. 3. Experiment 5 ('Lapins'/Mazzard, nursery, 2003). Note meter stick in each picture. (a) Very little spontaneous feather development in control trees; (b) good feathering induced higher up on leaders by CYC $100 \mathrm{mg} \cdot \mathrm{L}^{-1}$ applied 16 June; (c) some feathering induced by PR $500 \mathrm{mg} \cdot \mathrm{L}^{-1}$ applied 16 June; (d) tank-mix of CYC and PR applied 16 June.
Larsen, F.E. 1979. Chemical stimulation of branching in deciduous tree fruit nursery stock with ethyl 5-(4-chlorophenyl)-2H-tetrazole-2-acetate. J. Amer. Soc. Hort. Sci. 104:770-773.

Miller, P. 1983. The use of Promalin for manipulation of growth and cropping of young sweet cherry trees. J. Hort. Sci. 58:497-503.

Neri, D., M. Mazzoni, F.Zucconi, and G. Dradi. 2003.
Il controllo della formazione dei rami anticipati nel ciliegio dolce. Riv. Frutt. Ortofloricoltura 65:47-53.

Pederson, M.K., J.D. Burton, H.D. Coble, J.R. Collins, and D. Fritz. 1997. Efficacy of Finish and its mechanism of action. Proc. Beltwide Cotton Conf. 2:1363-1365.

Plich, H. and A. Basak. 1978. Further trials on induction of feathering in young apple and cherry nursery trees. Fruit Sci. Rpt. 5:23-33.

Preston, A.P. 1968. Pruning and rootstock as factors in the production of primary branches on apple trees. J. Hort. Sci. 43:17-22.

Quinlan, J.D. 1978. Chemical induction of lateral branches (feathers). Acta Hort. 80:129-138.

Quinlan, J.D. 1981. New chemical approaches to the control of fruit tree form and size. Acta Hort. 120:95-106.

Quinlan, J.D. and A.P. Preston. 1973. Chemical induction of branching in nursery trees. Acta Hort. 34:123-127.

Quinlan, J.D. and A.P. Preston. 1978. The use of branching agents to replace hand pruning of young trees of Bramley's Seedling apple. J. Hort. Sci. 53:39-43.

Snedecor, G.W. and W.G. Cochran. 1980. Statistical methods, p. 385-388. 7th ed. Section 18.9. Iowa State Univ. Press, Ames.

van Oosten, H.J. 1978. Effects of initial tree quality on yield. Acta Hort. 65:123-125.

van Oosten, H.J. 1981. Effects of propyl-3-t-butyl phenoxy acetate $(\mathrm{MB} 25,105)$ on the branching of maiden apple trees. Med. Fac. Landbouww. Rijksuniv. Gent 46/1:247-251.

Veinbrants, N. and P. Miller. 1981. Promalin promotes lateral shoot development of young cherry trees. Austral. J. Expt. Agr. Animal Husb. 21:618-622.

Wertheim, S.J. 1978. Manual and chemical induction of side-shoot formation in apple trees in the nursery. Scientia Hort. 9:337-345.

Wustenberghs, H. and J. Keulemans. 1999. Le cerisier a fruits doux:Amelioration de la qualite des plants. Le Fruit Belge 67:106-110. 